\title{
Potensi Antioksidan Alami pada Ekstrak Kulit Buah Jamblang (Syzigium cumini (L.) Skeels) Menggunakan Metode DPPH (The Potency of Natural Antioxidant in The Rind Extract of Jamblang (Syzigium cumini (L.) Skeels) using DPPH Method)
}

\author{
Ayu Nirmala Sari ${ }^{1}$, Kusdianti ${ }^{2}$, Diky Setya Diningrat ${ }^{3)}$ \\ 1) Jurusan Biologi, Fakultas Sains dan Teknologi, Universitas Islam Negeri Ar-RaniryBanda Aceh-Aceh \\ 2) Jurusan Biologi, FPMIPA, Universitas Pendidikan Indonesia Bandung - Jawa Barat \\ 3) Jurusan Biologi, Fakultas MIPA, Universitas Negeri Medan \\ Medan - Sumatera Utara \\ ${ }^{*}$ Email korespondensi: ayunirmala79@gmail.com
}

Diterima 30 Januari 2018, diterima untuk dipublikasi 27 Februari 2018

\begin{abstract}
Abstrak
Stress oksidatif pada tubuh dapat memicu berbagai penyakit. Stress oksidatif ini disebabkan karena radikal bebas berlebih. Tubuh memerlukan antioksidan untuk mengurangi pengaruh radikal bebas dan meredam dampak negatifnya. Penelitian ini bertujuan untuk mengevaluasi daya antioksidan ekstrak kulit buah jamblang (Syzigium cumini (L.) Skeels) dengan menggunakan metode DPPH. Berdasarkan hasil pengujian daya antioksidan ekstrak kulit buah jamblang diketahui bahwa ekstrak kulit buah jamblang memiliki kandungan antioksidan yang tergolong aktivitas sedang dengan nilai $I C_{50}$ sebesar 169.3. Hasil penelitian ini menunjukkan bahwa kulit buah jamblang berpotensi untuk dikembangkan sebagai sumber antioksidan alami bagi manusia.
\end{abstract}

Kata Kunci : antioksidan, DPPH, ekstraksi, jamblang, radikal bebas, stress oksidatif

\begin{abstract}
Oxidative stress can induce many diseases. Oxidative stress is caused by excessive free radicals in the body. The body required antioxidant to decrease and hush the negative effects of free radicals. The aim of this study was to evaluate the antioxidant potency of extract rind of jamblang (Syzigium cumini (L.) Skeels) using DPPH method. The result showed that the jamblang rind extract had moderate antioxidant activity and the $I C_{50}$ value was 169.3 . Based on this result, jamblang rind was potential to be natural antioxidant for human.

Keyword: antioxidant, DPPH, extraction, jamblang, free radicals, oxidative stress
\end{abstract}




\section{PENDAHULUAN}

Reaksi oksidasi berlebihan di dalam tubuh dapat menjadi awal dari berbagai penyakit. Reaksi yang terjadi setiap saat pada tubuh ini mencetuskan atau menghasilkan radikal bebas yang sangat aktif, yang dapat merusak struktur dan fungsi sel (Winarsih 2007). Pembentukan radikal bebas tersebut dapat terjadi melalui proses metabolisme sel normal, peradangan, kekurangan gizi, dan akibat respon terhadap pengaruh dari luar tubuh, seperti polusi lingkungan, ultraviolet, dan asap rokok (Winarsih 2007). Radikal bebas merupakan molekul yang memiliki elektron yang tidak berpasangan pada orbit terluarnya sehingga bersifat reaktif dan sangat mudah berikatan dengan unsur lain. Kondisi ini dapat memicu kerusakan pada DNA, lipid, protein dan karbohidrat sehingga menimbulkan berbagai penyakit seperti diabetes mellitus, kanker dan aterosklerosis (Chen et al. 2007).

Kadar radikal bebas dalam tubuh dapat dilihat dari aktivitas enzim antioksidan dan kadar malondialdehid (Zakaria et al. 2000). Kondisi ini menyebabkan sel-sel tubuh mengalami degenerasi, proses metabolisme terganggu dan respon imun menurun sehingga memicu munculnya berbagai penyakit degeneratif. Dibutuhkan antioksidan yang dapat membantu melindungi tubuh dari pengaruh radikal bebas dan meredam dampak negatifnya (Winarsih 2007). Antioksidan merupakan senyawa yang dapat menghambat spesies oksigen reaktif/spesies nitrogen reaktif (ROS/RNS) dan juga radikal bebas (Halliwell et al. 1992). Antioksidan menghambat reaksi oksidasi dan mencegah kerusakan sel dengan cara mengikat radikal bebas dan molekul yang sangat reaktif. Konsumsi antioksidan dalam jumlah yang memadai dilaporkan dapat menurunkan kejadian penyakit degeneratif, meningkatkan status imunologi dan menghambat timbulnya penyakit degeneratif akibat penuaan. Oleh sebab itu kecukupan asupan antioksidan secara optimal sangat diperlukan (Winarsih 2007).
Antioksidan yang banyak digunakan pada makanan umumnya adalah antioksidan sintetik seperti Butylated Hydroxyl Amisole (BHA), Butylated Hydroxytoluene (BHT) dan profil galat. Namun dilaporkan bahwa penggunaan antioksidan sintetik memberi dampak negatif pada kesehatan manusia yaitu berupa gangguan fungsi hati, paru, mukosa usus dan keracunan. Hal ini dapat terjadi jika penggunaan dosis antioksidan sintetis ini melebihi batas yang ditetapkan yaitu 0,01-0,1\% (Panagan 2011). Produk antioksidan sintetik ini juga dijual dengan harga yang mahal, padahal komponen antioksidan tersebut terdapat di alam secara melimpah, seperti pada tumbuhan (Winarsih 2007).

Terdapat banyak jenis tumbuhan yang telah terbukti memiliki kandungan antioksidan, diantaranya ekstrak etanol kulit buah manggis (Suryadi 2013), ekstrak daun kemuning (Rohman dan Riyanto 2005), dan ekstrak biji adas (Sastrawan et al. 2013). Jenis tanaman lain yang juga diduga memiliki kandungan antioksidan yang tinggi adalah (Syzigium cumini (L.) Skeels) atau yang dikenal dengan nama lokal jamblang (Siti Azima et al. 2014). Secara tradisional jamblang telah digunakan untuk sebagai antidiuretik, antidiabetes, obat diare, dan antimikroba (Veigas et al. 2007). Hal ini tentu bukan sesuatu yang tidak mungkin jika jamblang dijadikan sebagai obat untuk berbagai macam penyakit.

Senyawa bioaktif pada tanaman biasanya berupa metabolit sekunder (Veigas et al. 2007). Metabolit sekunder umumnya memiliki aktivitas biologis tertentu seperti alkaloid, terpenoid, flavonoid, tannin dan steroid. Fungsi dari metabolit sekunder adalah mempertahankan tanaman dari mikroba, melindungi dari predator, perlindungan terhadap lingkungan, serta sebagai toksik untuk mempertahankan kelangsungan hidup di alam (Hanani 2010). Metabolit sekunder tumbuhan inilah yang dapat bertindak sebagai antioksidan pada manusia yang dapat dijadikan sebagai bahan untuk mengeliminir radikal bebas. Metabolit sekunder umumnya terakumulasi 
pada salah satu organ tanaman seperti daun, akar, batang, biji, buah dan kulit buah. Berdasarkan hal tersebut pada penelitian ini dilakukan untuk melihat aktivitas antioksidan dari ekstrak metanol kulit buah jamblang dengan metode diphenylpicrylhydrazyl (DPPH).

\section{METODE \\ Ekstraksi Etanol Kulit Buah Jamblang}

Prosedur pembuatan ekstrak etanol kulit buah Jamblang menurut Siti Azima et al. (2014) yakni dengan cara ekstraksi metode maserasi dengan pelarut metanol $96 \%$. Sampel segar dihaluskan dengan blender hingga berbentuk simplisia. Simplisia ditambahkan pelarut metanol $96 \%$ dengan perbandingan jumlah simplisia dan etanol yakni untuk $100 \mathrm{~g}$ simplisia ditambahkan etanol sebanyak $1 \mathrm{~L}$. Perendaman simplisia selama lima hari dan diaduk sesekali. Selanjutnya rendaman disaring menggunakan kertas saring dan pada ampas simplisia ditambahkan pelarut etanol 96\% kembali, kemudian didiamkan selama lima hari lagi dan kembali disaring. Ekstrak yang diperoleh dipekatkan dengan menggunakan dryer untuk mendapatkan ekstrak metanol berbentuk pasta.

\section{Uji aktivitas antioksidan dengan metode DPPH}

Sebanyak $100 \mu \mathrm{L}$ ekstrak (dengan berbagai konsentrasi), ditambah $1,0 \mathrm{~mL}$ DPPH 0,4 mM dan etanol sampai $5,0 \mathrm{~mL}$. Campuran selanjutnya divorteks dan dibiarkan selama 30 menit. Larutan ini selanjutnya diukur absorbansinya pada panjang gelombang $515 \mathrm{~nm}$. Dilakukan juga pengukuran absorbansi blanko. Hasil penetapan antiioksidan dibandingkan dengan vitamin E. Besarnya daya antioksidan dihitung dengan rumus (absorbansi blanko - absorbansi sampel)/ absorbansi blanko x 100\% (Takaya et al. 2003).

\section{HASIL DAN PEMBAHASAN}

Daya antioksidan dengan metode DPPH Uji daya antioksidan dengan metode DPPH (2,2-difenil-1-pikril hidrazil) dimaksudkan untuk menguatkan aktivitas suatu senyawa uji (ekstrak methanol kulit buah jamblang) sebagai antioksidan (Takaya, et al., 2003). DPPH merupakan radikal sintetik yang larut dalam pelarut polar seperti metanol dan etanol. DPPH merupakan radikal yang stabil yang dapat diukur intensitasnya pada panjang gelombang $515 \mathrm{~nm}$. Hasil pengukuran daya antioksidan ekstrak etanol daun kemuning dengan menggunakan metode DPPH (Tabel 1). Sebagai pembanding digunakan vitamin $\mathrm{E}$ yang sudah diketahui sebagai antioksidan. Hasil pengukuran daya antioksidan vitamin $\mathrm{E}$ dengan metode DPPH (Tabel 2 ).

Tabel 2 menunjukkan bahwa ekstrak methanol kulit buah jamblang mempunyai daya antioksidan dengan metode $\mathrm{DPPH}$ dengan nilai $I_{50}$ sebesar $169,3 \mu \mathrm{g} / \mathrm{mL}$. IC50 merupakan konsentrasi kulit buah jamblang yang mampu memberikan persen penangkapan radikal sebanyak 50\% dibanding kontrol melalui suatu persamaan garis regresi linier, semakin kecil nilai IC50 berarti semakin kuat daya antioksidannya. Nilai $I_{50}$ ini jauh lebih besar daripada nilai $\mathrm{IC}_{50}$ vitamin $\mathrm{E}$ yakni sebesar $8,27 \mu \mathrm{g} / \mathrm{mL}$. $\mathrm{Hal}$ ini menunjukkan bahwa daya antioksidan ekstrak ekstrak metanol kulit buah jamblang 15 kali lebih kecil dibanding dengan daya antioksidan vitamin $\mathrm{E}$ dengan menggunakan metode DPPH.

\section{KESIMPULAN}

1. Ekstrak methanol kulit buah jamblang menunjukkan daya antioksidan dengan metode DPPH secara in vitro.

2. Dengan metode DPPH, ekstrak metanol kulit buah jamblang mempunyai daya antioksidan yang ditandai dengan menurunnya absorbansi ekstrak 1\%, 5\% dan $10 \%$ dibandingkan kontrol secara signifikan. 
Tabel 1. Hubungan antara kadar ekstrak methanol kulit buah jamblang dengan daya antioksidan dengan metode DPPH

\begin{tabular}{cccl}
\hline $\begin{array}{c}\text { Kadar ekstrak } \\
\text { metanol }(\mu \mathrm{g} / \mathrm{mL})\end{array}$ & $\begin{array}{c}\text { Absorbansi } \\
\text { sampel }\end{array}$ & $\begin{array}{c}\text { Aktivitas } \\
\text { antioksidan }(\%)\end{array}$ & $\begin{array}{l}\text { Persamaan garis } \\
\text { regresi linier })\end{array}$ \\
\hline 50 & 0,783 & 14,519 & $\mathrm{y}=0,2908+06769$ \\
100 & 0,625 & 31,715 & $\mathrm{r}=0,9949$ \\
150 & 0,493 & 46,345 & $\mathrm{IC}_{50}=169,3 \mu \mathrm{g} / \mathrm{mL}$ \\
200 & 0,396 & 56,715 & \\
& & &
\end{tabular}

Tabel 2. Hubungan antara kadar vitamin $\mathrm{E}$ dengan daya antioksidan dengan metode DPPH

\begin{tabular}{cccl}
\hline $\begin{array}{c}\text { Kadar Vitamin E } \\
(\mu \mathrm{g} / \mathrm{mL})\end{array}$ & $\begin{array}{c}\text { Absorbansi } \\
\text { sampel }\end{array}$ & $\begin{array}{c}\text { Aktivitas } \\
\text { antioksidan }(\%)\end{array}$ & $\begin{array}{l}\text { Persamaan garis } \\
\text { regresi linier }\end{array}$ \\
\hline 2,5 & 0,792 & 12,43 & $\mathrm{y}=6,588 \times-4,46$ \\
5,0 & 0,648 & 28,28 & $\mathrm{r}=0,9995$ \\
7,5 & 0,505 & 44,10 & $\mathrm{IC}_{50}=8,27 \mu \mathrm{g} / \mathrm{mL}$ \\
10 & 0,343 & 62,06 & \\
20 & 0,116 & 87,17 &
\end{tabular}

\section{UCAPAN TERIMA KASIH}

Ucapan terima
disampaikan
kepada Jurusan Biologi, Fakultas Sains dan Teknologi, dan LPPM Universitas Islam Negeri Ar-Raniry Banda Aceh yang membiayai penelitian ini. Jurusan Biologi, FPMIPA, Universitas Pendidikan Indonesia, Bandung - Jawa Barat dan Jurusan Biologi, Fakultas MIPA, Universitas Negeri Medan, Medan-Sumatera Utara yang telah memfasilitasi penelitian ini.

\section{DAFTAR PUSTAKA}

Chen LH, Yang L, Wang C (2007) Anti-inflamatory Activity of Mangostins from Garcinia mangostana. Food and Chemical Toxicology 46(2): 688-693

Halliwell B, Gutteridge JMC, Cros CE (1992) Free Radicals,
Antioxidants and Human Desease: Where Are We Now?. Journal of Laboratory Clinical Medicine 119(6): 598620

Hanani E (2010) Herbal Indonesia Berkhasiat. Trubus InfoKit 8: 560

Jun MHY, Fong X, Wan CS, Yang CT, Ho (2003) Comparison of antioxidant activities of isoflavones from kudzu root (Pueraria labata Ohwl). Journal Food Sci. Institute of Technology $68: 2117-2122$

Panagan AT (2011) Pengaruh Penambahan Tepung Wortel (Daucus carota L.) terhadap Bilangan Peroksida dan Asam Lemak Bebas pada Minyak Goreng Curah. Jurnal Penelitian Sains

Rohman A, Riyanto S (2005) Daya Antioksidan Ekstrak Etanol Daun Kemuning (Murraya 
paniculata $\mathrm{L}$ Jack) secara In Vitro. Majalah Farmasi Indonesia 16(3): 136-140

Sastrawan IN, Sangi M, Kamu V (2013) Skrining Fitokimia dan Uji Aktivitas Antioksidan Ekstrak Adas (Foeniculu vulgare) Mengunakan Metode DPPH. Jurnal IImiah Sains 13(2): 112-115

Siti Azima AM, Noriham A, Manshoor N (2014) Anthocyanin content in relation to the antioxidant activity and colour properties of Garcinia mangostana peel, Syzigium cumini and Clitoria ternatea extracts. International Food Research Journal 21(6)

Suryadi J (2013) Daya Antioksidan Ekstrak Etanol Kulit Buah Manggis (Garcinia mangostana L.) Pengeringan Matahari Langsung dan Freeze Drying. Jurnal IImiah Mahasiswa Universitas Surabaya 2(1):1-19
Takaya Y, Kondo Y, Furukawa T, Niwa M (2003) Antioxidant Constituents of Radish Sprout (Kaiware-daikon), Raphanus sativus L, Journal Agric Food Chem 51:8061-8066

Veigas J, Narayan MS, Laxman PM, Neelwarne B (2007) Chemical nature, stability and bioefficacies of anthocyanins from fruit peel of Syzygium cumini Skeels. Food Chemistry 105:619-627

Winarsih (2007) Antioksidan Alami dan Radikal Bebas. Yogyakarta: Kanisius

Zakaria FRH, Susanto, Hartoyo A (2000) Pengaruh Konsumsi Jahe (Zingiber officinale Roscoe) terhadap Kadar Malondialdehid dan Vitamin E Plasma pada Mahasiswa Pesantren Ulil Albaab Kedung Badak Bogor. Jurnal Teknologi dan Industri Pangan 11(1): 36-40 